\title{
Effects of fine-scale oceanographic features on the distribution and movements of harbour porpoises Phocoena phocoena in the Bay of Fundy
}

\author{
D. W. Johnston ${ }^{1,2,3, *}$, A. J. Westgate ${ }^{1,4}$, A. J. $\operatorname{Read}^{1}$ \\ ${ }^{1}$ Nicholas School of the Environment and Earth Sciences, Duke University Marine Laboratory, 135 Duke Marine Lab Road, \\ Beaufort, North Carolina 28516, USA \\ ${ }^{2}$ Monterey Bay Aquarium Research Institute, 7700 Sandholdt Road, Moss Landing, California 95039-9644, USA \\ ${ }^{3}$ Present address: National Marine Fisheries Service, Pacific Islands Fisheries Science Center, 2570 Dole Street, Honolulu, \\ Hawaii 96822, USA \\ ${ }^{4}$ Present address: University of North Carolina Wilmington, 601 South College Road, Wilmington, North Carolina 28403, USA
}

\begin{abstract}
We describe an integrative approach to studying the fine-scale distribution of harbour porpoises Phocoena phocoena in the Bay of Fundy, using satellite telemetry, line transect surveys and remote sensing techniques. Analysis of satellite telemetry data from 6 porpoises ( 5 male, 1 female) revealed that over the course of a month individuals ranged across large areas (7738 to $\left.11289 \mathrm{~km}^{2}\right)$ but concentrated their movements in small focal regions (August mean $=294 \mathrm{~km}^{2}$, September mean $\left.=252 \mathrm{~km}^{2}\right)$, often proximate to islands, headlands, or restricted channels. Line transect surveys $(\mathrm{n}=$ 25 flood tide, $\mathrm{n}=20 \mathrm{ebb}$ tide) in the focal region of 2 tagged animals revealed that relative porpoise density (animals $\mathrm{km}^{-2}$ ) was significantly greater during flood (9.59) than ebb tide phases (1.79). Hydro-acoustic prey surveys revealed aggregations of prey along localized fronts in this region. Remote sensing images indicated the presence of an island wake in the focal region during flood tides, providing an ecological context for our observations of high densities of porpoises. Remote sensing revealed the existence of a headland wake in the focal region of another porpoise near Campobello Island. These results support the hypothesis that regions of enhanced relative vorticity, like island and headland wakes, aggregate prey and represent important foraging habitat for harbour porpoises in the Bay of Fundy.
\end{abstract}

KEY WORDS: Harbour porpoise $\cdot$ Foraging $\cdot$ Fine-scale oceanography $\cdot$ Island wake $\cdot$ Satellite telemetry $\cdot$ Line transects $\cdot$ Remote sensing

\section{INTRODUCTION}

Many large marine predators use vast areas of the ocean, but typically concentrate their activities in smaller, localized regions for periods of time. For example, many species of pelagic seabirds, such as albatrosses, range across entire ocean basins, but forage in small areas for extended periods (Hyrenbach \& Dotson 2001, Hyrenbach et al. 2002). Some marine mammals undertake long annual migrations, but return seasonally to forage in localized areas (Stewart \& Delong 1995, Read \& Westgate 1997, Mate et al.
1999, Baumgartner et al. 2003). Such distribution patterns are usually interpreted as the result of foraging decisions made at meso- (10s to $100 \mathrm{~s}$ of $\mathrm{km}$ ) and finescales $(1$ to $10 \mathrm{~km})$, based on the assumption that such highly mobile animals will remain near a prey patch until it becomes energetically profitable to move on to the next patch (MacArthur \& Pianka 1966, Charnov 1976, Stephens \& Krebs 1986).

In marine systems, heterogeneity of productivity is the result of complex interactions of wind, currents, and land masses. At fine-scales (1 to $10 \mathrm{~km}$ ), oceanographic features such as upwellings, fronts, and eddies 
can increase primary productivity (St. John \& Pond 1992, St. John et al. 1992) and physically aggregate plankton and weak nekton (Wolanski \& Hamner 1988, Mann \& Lazier 1996). This, in turn, attracts larger numbers of small consumers - often schooling fish-and results in localized patches of food for marine predators that feed at low and medium trophic levels. It is now recognized that such fine-scale oceanographic features can be of great importance to pelagic predators (Wolanski \& Hamner 1988), providing mechanisms which enhance concentrations of prey that can be exploited by whales, seabirds and large pelagic fishes (e.g. Brodie et al. 1978).

Harbour porpoises Phocoena phocoena are small odontocete cetaceans that inhabit the temperate waters of the northern hemisphere in a nearly circumpolar distribution (Gaskin 1984). Throughout this range, their distribution is restricted to waters of the continental shelf (Read 1999). In the Bay of Fundy, harbour porpoises feed primarily on juvenile Atlantic herring Clupea harengus harengus (Smith \& Gaskin 1974, Recchia \& Read 1989, Gannon et al. 1998), although weaning calves consume euphausiids Meganyctiphanes norvegica (Smith \& Read 1992). In both the summer and fall, Atlantic herring comprise the largest portion of the diet. In the fall, however, porpoises expand their diet to a wider range of prey as they move south into the Gulf of Maine (Gannon et al. 1998), including silver hake Merluccius bilinearis, hake Urophycis spp. and pearlsides Maurolicus weitzmani. Because of their small size, harbour porpoises are unable to carry large energy stores (Koopman 1998), so their patterns of movement are likely to be strongly related to the distribution of their prey.

Previous studies in the Bay of Fundy and Gulf of Maine indicate that porpoise movements occur on at least 2 spatial and temporal scales. Individuals inhabit relatively restricted areas for days to weeks (finescales) and then make rapid movements over periods of hours to days across larger scales (meso-scales) to other restricted areas (Read \& Westgate 1997). Telemetry studies of harbour porpoises in European waters reveal similar patterns (Teilmann 2000). It remains unclear, however, what environmental factors drive their distribution at both large and small scales (Watts \& Gaskin 1985, Cox 2003). In the early 1980s, D. Gaskin hypothesized that tidally driven oceanographic features in the Bay of Fundy might concentrate zooplankton and small fishes, making these prey more available to harbour porpoises and other marine predators (Jovallanos \& Gaskin 1983, Smith et al. 1984). Gaskin's work described the habitat of harbour porpoises in the Bay of Fundy, but it did not explain how environmental characteristics influenced the distribution of porpoises at fine-scales (Watts \& Gaskin 1985).
The purpose of the present study was to address Gaskin's original hypothesis in greater detail by examining the distribution and movements of harbour porpoises in the Bay of Fundy during the summer months (a period of high porpoise abundance) in relation to fine-scale oceanography. Specifically, we hypothesized that harbour porpoises in the Bay of Fundy exploit predictable fine-scale oceanographic features that aggregate prey to facilitate foraging. To do this, we chose an integrative approach, first using satellite telemetry data to examine the movements and distribution of harbour porpoises and to identify focal regions of porpoise distribution. We then employed line transects, hydro-acoustic surveys of prey and remote sensing techniques to explore why porpoises utilized these core regions of habitat.

\section{MATERIALS AND METHODS}

Satellite telemetry. Study area and timeframe: We obtained positional data from satellite-linked transmitters attached 6 to harbour porpoises released from herring weirs around Grand Manan Island, New Brunswick, Canada $\left(44^{\circ} 45^{\prime} \mathrm{N}, 66^{\circ} 45^{\prime} \mathrm{W}\right.$; Fig. 1). These 6 represent a subset of harbour porpoises tagged and released as part of a larger study during the summers (July to September) of 1995 to 2000, as described in Read \& Westgate (1997), Westgate \& Read (1998) and Neimanis et al. (2004). Briefly, the dorsal fin of each porpoise was fitted with a satellite-linked transmitter, also referred to as a platform terminal transmitter (PTT). The mass of these tags represents a small proportion of a porpoises mass $(<1 \%)$ and we assumed that any effects of the capture process, or of carrying the tag, were short in duration (Read \& Westgate 1997). Individual tags varied in the time they transmitted data, with the shortest providing locations for $78 \mathrm{~d}$ and the longest for $174 \mathrm{~d}$. The tags were programmed to transmit on various duty cycles: 2 tags transmitted for $6 \mathrm{~h}$ followed by $16 \mathrm{~h}$ of quiescence (PTT 16291 \& PTT16300); the remaining 4 tags initially transmitted for $8 \mathrm{~h}$ followed by $16 \mathrm{~h}$ of quiescence. After $10 \mathrm{~d}$ the latter 4 tags reverted to $6 \mathrm{~h}$ of transmission followed by $16 \mathrm{~h}$ of quiescence.

Data treatment and spatial analysis: To maximize our sample of observations for each animal, and to maintain consistency among data sets, we only examined porpoises tagged during the early summer (before 10 August). Positional data were filtered to remove erroneous positions using a 2-stage speed filter (McConnell et al. 1992, Austin et al. 2003) and further subsampled by eliminating points which were obtained within less than $1.5 \mathrm{~h}$ of each other, to maintain a relatively consistent sampling rate. Table 1 provides infor- 

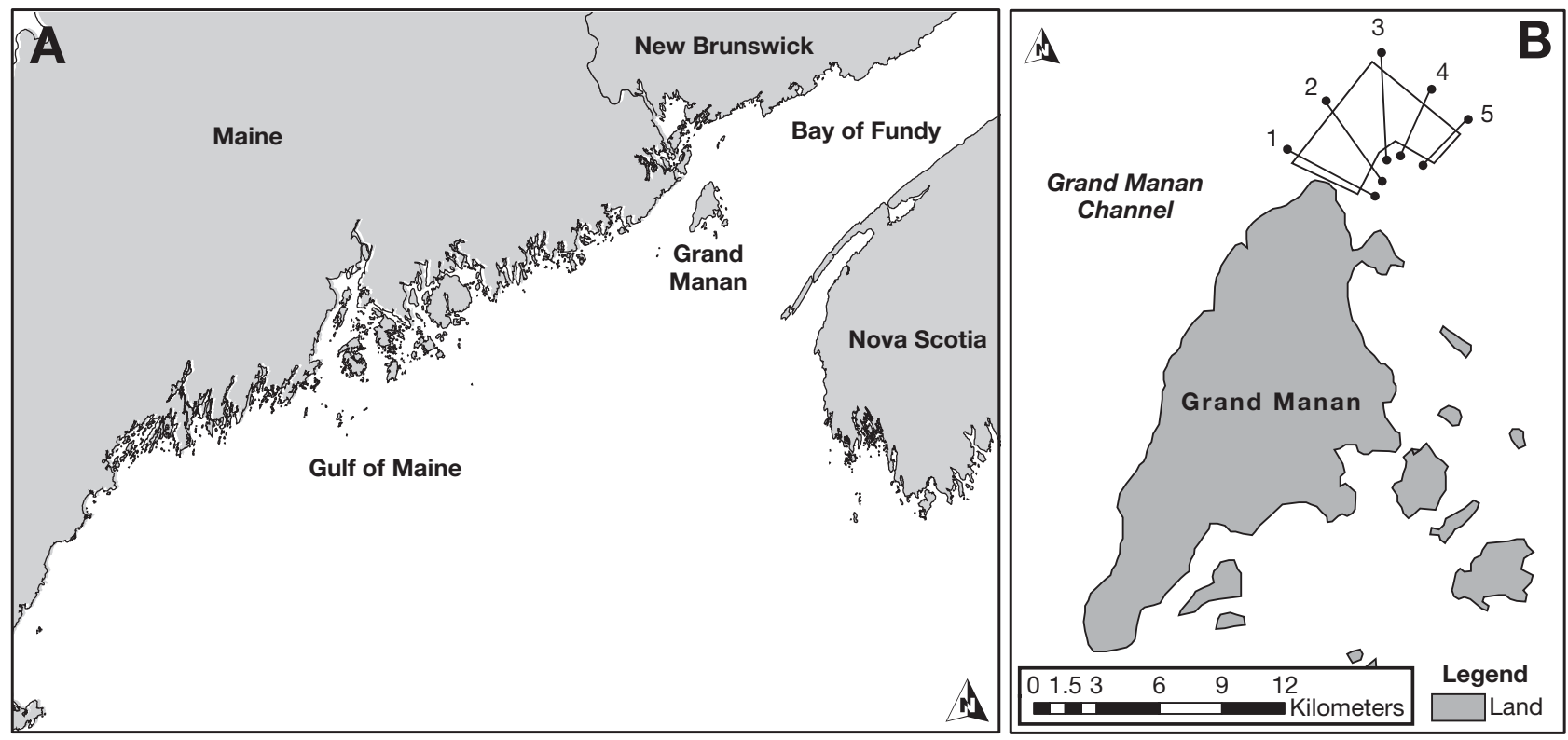

Fig. 1. Study area, detailing (A) the Gulf of Maine and Bay of Fundy and the location of Grand Manan Island and (B) the location of line transects and hydro-acoustic prey surveys (labelled 1 through 5)

mation on each tagged porpoise and details on transmission period for each tag. Summaries of the number of positions and the minimum timing between subsequent telemetry positions for each animal used in our analysis are also provided in Table 1.

We imported the telemetry data into ArcGIS 8.1 (ESRI) and mapped these observations with the Zone 19 (N) Universal Transverse Mercator (UTM) projection, using the WGS 1984 datum. We produced monthly Kernel density utilization grids for each porpoise using 1 to 3 telemetry positions per tide phase (flood or ebb and excluding those on land) to illustrate the fine-scale regions used by the porpoises. We calculated utilization grids with the Kernel Density function in the Spatial Analyst extension in ArcGIS 8.1 with a search radius of $10000 \mathrm{~km}^{2}$ and an output cell size of
$1 \mathrm{~km}^{2}$. We relaxed the frequently asserted requirement for independence of telemetry observations to maximize sample size and increase the precision and accuracy of utilization distributions for our fine-scale analysis (De Solla et al. 1999).

We categorized kernel density grids into 5 separate regions: cells where porpoise density was 0 , and cells corresponding to the 25th, 50th, 75th and 95th percentiles of the density of position estimates. To draw comparisons among telemetered animals, we calculated the area of focal regions ( $95 \%$ density-to identify the core region that porpoises used) and range regions (to the $0 \%$ contour - to illustrate the extent to which each animal moved during the month) by enumerating all focal and range grid cells not covered by land. To illustrate fine-scale movements of porpoises,

Table 1. Phocoena phocoena. Life history and telemetry data details for harbour porpoises employed in kernel density utilization grid analysis. The average time between samples did not include the duty cycle of the tag

\begin{tabular}{|c|c|c|c|c|c|c|c|c|c|c|c|c|}
\hline \multirow[t]{2}{*}{ ID } & \multirow[t]{2}{*}{ Nickname } & \multirow[t]{2}{*}{ Tag date } & \multirow[t]{2}{*}{ Last day } & \multirow{2}{*}{$\begin{array}{l}\text { Duration } \\
\text { (d) }\end{array}$} & \multirow[t]{2}{*}{ Sex } & \multirow{2}{*}{$\begin{array}{l}\text { Length } \\
\text { (cm) }\end{array}$} & \multirow{2}{*}{$\begin{array}{l}\text { Weight } \\
(\mathrm{kg})\end{array}$} & \multirow{2}{*}{$\begin{array}{l}\text { Percent } \\
\text { rejected } \\
\text { by filter }\end{array}$} & \multirow{2}{*}{\multicolumn{2}{|c|}{$\begin{array}{l}\text { August } \\
\text { No. of Time between } \\
\text { positions } \quad \text { samples }\end{array}$}} & \multicolumn{2}{|c|}{ - September -} \\
\hline & & & & & & & & & & & $\begin{array}{c}\text { No. of } \\
\text { positions }\end{array}$ & $\begin{array}{l}\text { Time between } \\
\text { samples }\end{array}$ \\
\hline PTT7235 & David & 2 Aug 1999 & 17 Jan 2000 & 168 & M & 150 & 53 & 18.0 & 90 & 2.0 & 72 & 2.0 \\
\hline PTT 7244 & Mitchell & 9 Aug 1999 & 18 Jan 2000 & 162 & $\mathrm{M}$ & 150 & 56 & 12.6 & 64 & 2.3 & 65 & 1.7 \\
\hline PTT 16291 & Otis & 9 Aug 1997 & 9 Dec 1997 & 122 & $\mathrm{M}$ & 146.5 & 48 & 30.0 & 45 & 2.1 & 67 & 2.0 \\
\hline PTT 7250 & Sacagawea & 8 Aug 1998 & 25 Oct 1998 & 78 & $\mathrm{~F}$ & 164 & 53 & 23.1 & 37 & 2.1 & 47 & 1.8 \\
\hline PTT 16300 & Shackleton & 6 Aug 1998 & 24 Nov 1998 & 110 & $\mathrm{M}$ & 138 & 43 & 20.4 & 64 & 1.8 & 72 & 1.8 \\
\hline \multirow[t]{3}{*}{ PTT 8531} & Stanley & 29 Jul 1999 & 19 Jan 2000 & 174 & $\mathrm{M}$ & 132 & 38.6 & 14.0 & 55 & 1.8 & 63 & 1.7 \\
\hline & Mean & & & 136 & & 147 & 48.6 & 19.7 & 59.2 & 2.0 & 64.3 & 1.8 \\
\hline & SD & & & 38 & & 11 & 6.7 & 6.4 & 18.5 & 0.2 & 9.2 & 0.1 \\
\hline
\end{tabular}


we imported the telemetry data into ArcView 3.2 (ESRI) and connected lines between subsequent (chronological) positions with the Animal Movement Extension (Hooge \& Eichenlaub 1997). Movement polylines were then mapped in ArcGIS 8.1 and projected as above.

Line transect surveys. Study area and timeframe: We conducted a series of fine-scale line transect surveys in one of the focal regions identified by the preceding telemetry analysis to assess porpoise density in August 2000. This area, located off the north tip of Grand Manan Island (Fig. 1), attracts large numbers of marine predators, presumably to forage in the tidal fronts and eddies that form during the flood tide. We conducted preliminary theodolite surveys in July 2000 to define the region to be sampled by line transect surveys. From these observations we defined a $24 \mathrm{~km}^{2}$ region that encompassed the visible surface effects of a localized oceanographic feature that formed on flood tides, by recording the spatial location of obvious surface turbulence with a Geodimeter Total Station Model 600 digital theodolite (Spectra Precision Software) using methods described in Johnston (2002) and Ronconi \& St. Clair (2002). Briefly, the extent of the feature was delineated by recording its outer edge and marking all inflection points along this boundary. Vertical angles, horizontal angles and station height were used to calculate the distance to points sighted offshore. To account for tidal fluctuations, the station height for a given day and time was calculated using tidal amplitude as determined with WXTide32 (Version 3.0) and corrected for Northern Head, Grand Manan Island. We converted each point to northings and eastings relative to the theodolite station and, subsequently, to geographic coordinates. Finally, we mapped a polygon encompassing the perimeter of the feature (Fig. 1) using ArcGIS 8.1.

Line transects, sampling and density estimation: We established a series of 5 line transects of unequal length (Thomas et al. 2002a), each of which crossed the gradient of the major arc of the oceanographic feature defined by the theodolite survey (Fig. 1). We conducted surveys along these transects in August 2000 on clear days with a Beaufort Sea State of 2 or less. Each transect was sampled daily for a single tide phase (ebb or flood), starting at $1 \mathrm{~h}$ following slack tide and finishing at approximately $5 \mathrm{~h}$ past slack tide. The order in which transects were conducted and the starting point for each transect was randomized for each survey day. The distance sampling method typically requires that transects are randomly placed within the area of interest to generate density estimates (Thomas et al. 2002a), but we wanted to ensure that our transects did not run parallel to the axis of the oceanographic feature during flood tides, which exhibited a predictable arc within the study area (Fig. 1). Transects that paralleled the feature could lead to biased sampling of the region if porpoises were attracted to it (Buckland et al. 1993). Therefore, we report only relative porpoise density for the study region.

We conducted line transect surveys in our research vessel 'Ahqik', a 6 m Fundy runabout with methods similar to those used for other fine-scale surveys of small cetaceans using small vessels (Dawson et al. 2004). All surveys were conducted by the same 2 observers -1 at starboard and 1 to port-with eye level approximately $2 \mathrm{~m}$ above water. Each observer scanned a $90^{\circ}$ arc on their side of the vessel and recorded observations of the radial distance and bearing to groups of porpoises encountered on the survey. The observers also made estimates of the size of each group. Observers were randomly assigned an initial position, and alternated between port and starboard for each subsequent survey on that day. The boat driver recorded sightings of animals along the track line. The observers and driver were all experienced at sighting porpoises, and we conducted a series of training surveys with objects at known distances to ensure estimated radial distances to groups of porpoises were both accurate and consistent.

We generated density estimates from these surveys using Distance 4.0 software and the conventional distance sampling analysis engine (Thomas et al. 2002b) with the following parameter estimation specifications. Encounter rate, expected cluster size and density were estimated by tide phase (stratum) and the detection probability generated for all data combined. Our analysis considered exact distances to groups of observed porpoises, and the transect strip width estimation was based on the largest observed distance to a group of porpoises. The model used a half-normal key detection function with automatic selection of adjustment terms. The appropriate detection function was chosen automatically based on minimum Akaike Information Criterion (AIC). We did not attempt to correct our analysis for animals that may have been missed on the trackline.

Hydro-acoustic prey surveys and mid-water trawls: We conducted a series of hydro-acoustic prey surveys in the fine-scale study area on 15 and 16 August 2000 using a Simrad SM2000 $200 \mathrm{kHz}$ multibeam sonar (produces 128 beams in $180^{\circ}$ semi circle with each ping) and a Simrad $50 \mathrm{kHz}$ single beam sounder in a towable body deployed from a $12 \mathrm{~m}$ commercial fishing vessel. This equipment is used in herring stock assessments in the Bay of Fundy and is described in detail in Melvin et al. (2003). We completed 4 surveys of all 5 transects defined above during the flood tide phase, as well as a single transect along the length of 
the oceanographic feature during the flood tide. We subsequently conducted several mid-water trawls along the length of the oceanographic feature in August 2002 using a modified Isaacs-Kidd mid-water trawl towed at $1.5 \mathrm{~m} \mathrm{~s}^{-1}$.

Remote sensing. RADARSAT synthetic aperture radar: Oceanographic features may be visualized by synthetic aperture radar (SAR) sensors from patterns of surface roughness caused by interactions of wind and currents (Martinez et al. 1992) at shear or convergence zones. This type of remote sensing is frequently used in marine science and conservation, including oil spill detection (e.g. Lu 2003) and the visualization of finescale oceanographic features (e.g. Farmer et al. 1995).

We obtained an SAR image encompassing the finescale study area at approximately mid-flood $(2.25 \mathrm{~h}$ before a high tide of $5.36 \mathrm{~m}$ above mean low water). This image was obtained through the Data for Research Use Program of the Canadian Space Agency and covered the area within the following coordinates in decimal degrees: upper left corner - latitude $=45.049735^{\circ}$, longitude $=-67.174257^{\circ}$; upper right corner - latitude $=$ $45.032944^{\circ}$, longitude $=-66.322946^{\circ} ;$ l lower left corner latitude $=44.503460^{\circ}$, longitude $=-67.191396^{\circ} ;$ and lower right corner - latitude $=44.486984^{\circ}$, longitude $=$ $-66.348056^{\circ}$. The image was collected with fine beam mode, in the F1 near position, producing a nominal swath of $50 \times 50 \mathrm{~km}$ with a resolution of less than $8 \mathrm{~m}$. We obtained the image from RSI as a Map Image product (corrected to North Up orientation and geo-referenced for use in image-analysis and GIS applications) in the RADARSAT CEOS format, analyzed it with ERDAS Imagine 8.6 Version (Leica Geosystems GIS \& Mapping) and then exporting the image as an ARC grid image for incorporation into the GIS.

LANDSAT 7 CanImage: Physical and biological oceanographic features are also detectable by remote sensing satellites, which detect energy reflected (or the lack of it) from the Earth's surface at various wavelengths (Wolanski et al. 1984, Ekstrand 1992, Lubin et al. 2001). We obtained an archived CanImage orthoimage from the Canadian Centre for Topographic Information (Department of Natural Resources, Government of Canada) archive to search for oceanographic features in our fine-scale study area. CanImages are raster images derived from LANDSAT 7 orthoimages that have been resampled and based on the National Topographic System (NTS) at the 1:50 000 scale. CanImage comprise 7 spectral bands: a panchromatic band with a pixel size of $15 \mathrm{~m}$ and 6 multispectral bands with a pixel size of $30 \mathrm{~m}$. They are produced in accordance with North American Datum 1983 (NAD83) using the UTM projection (Anonymous 2002). We used catalog image NTS 021B10 with 3 spectrum bands-infrared $(0.750-0.900 \mu \mathrm{m})$, red $(0.630-0.690 \mu \mathrm{m})$ and green
(0.525-0.605 $\mu \mathrm{m})$ - often used to enhance the appearance of hydrographic features. The original image was obtained by the satellite on the 29 September 2000 at 15:04:10 h GMT, during a flood tide phase, approximately $1.35 \mathrm{~h}$ before a high tide of $6.26 \mathrm{~m}$ above mean low water. This image covered these coordinates in decimal degrees: upper left corner - latitude $=44.75^{\circ}$, longitude $=-67.00^{\circ}$; upper right corner - latitude $=$ $44.75^{\circ}$, longitude $=-66.50^{\circ}$; lower left corner - latitude $=44.50^{\circ}$, longitude $=-67.00^{\circ}$; and lower right corner latitude $=44.50^{\circ}$, longitude $=-66.50^{\circ}$. We also analyzed this image with ERDAS Imagine 8.6 and subsequently exported it as an ARC grid image for incorporation into the GIS.

\section{RESULTS}

\section{Satellite telemetry}

The kernel density utilization grids (representing porpoise density probabilities in percentiles) are presented in Figs. 2 to 7 . The areas within which porpoises traveled within a month varied considerably, but each porpoise exhibited a core-use area, surrounded by a larger region that was occasionally visited. The monthly core and range areas for each porpoise are presented in Table 2. Most porpoises restricted their movements to the western Bay of Fundy, close to Campobello and Grand Manan Islands. The core areas for each porpoise did not overlap, except for those of PTT16300 and PTT7235, whose August and September core areas both encompassed the northern end of Grand Manan (Figs. 2 \& 6). There was no consistent shift in ranges between months. Animals PTT7235, PTT7250 and PTT16300 ranged over larger areas in September (Figs. 2, 5 \& 6, Table 2), but PTT16291 and PTT8531 exhibited a smaller range in September than August (Figs. 4 \& 7, Table 2).

Table 2. Phocoena phocoena. Core and range areas $\left(\mathrm{km}^{2}\right)$ for telemetered harbour porpoises in the Bay of Fundy/Gulf of Maine generated by kernel density analysis for August and September. PTT: platform terminal transmitter

\begin{tabular}{|llcccc|}
\hline \multirow{2}{*}{ PTT } & \multirow{2}{*}{ Porpoise } & \multicolumn{2}{c}{ August } & \multicolumn{2}{c|}{ September } \\
& & Core & Range & Core & Range \\
& & & & & \\
7235 & PTT7235 & 269.0 & 8428.0 & 246.0 & 22103.0 \\
7244 & PTT7244 & 269.0 & 8421.0 & 226.0 & 8726.0 \\
16291 & PTT16291 & 415.0 & 10577.0 & 384.0 & 9694.0 \\
7250 & PTT7250 & 254.0 & 4728.0 & 229.0 & 11435.0 \\
16300 & PTT16300 & 234.0 & 5283.0 & 307.0 & 12923.0 \\
8531 & PTT8531 & 323.0 & 8990.0 & 122.0 & 2850.0 \\
& Mean & 294.0 & 7737.8 & 252.3 & 11288.5 \\
& SD & 66.2 & 2265.3 & 87.9 & 6324.0 \\
\hline
\end{tabular}



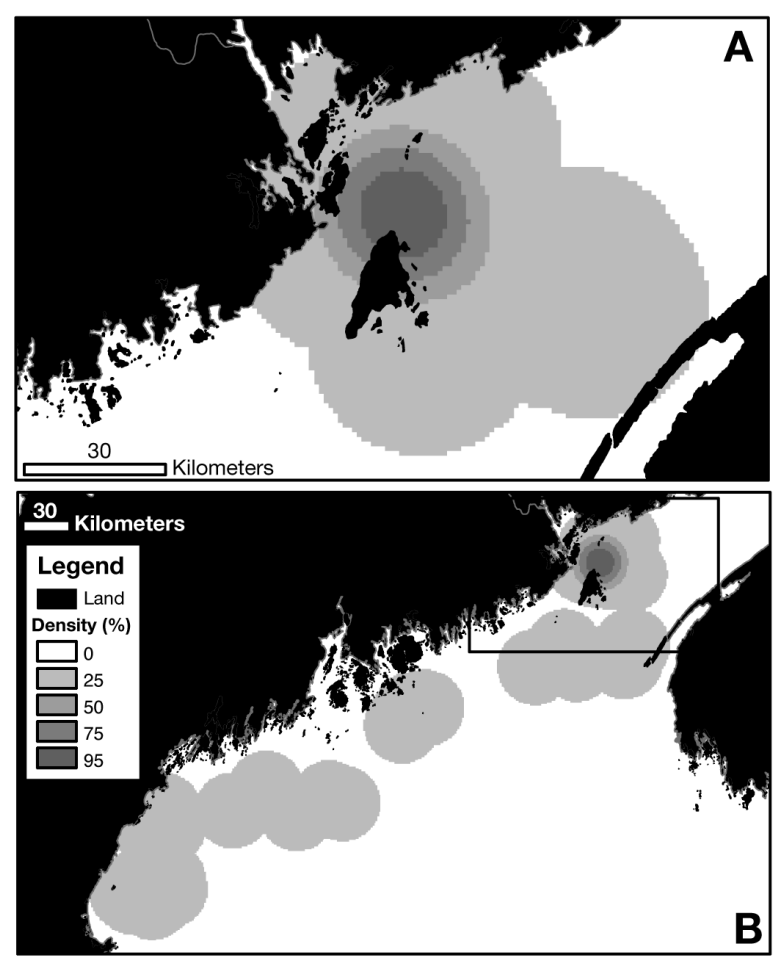

Fig. 2. Phocoena phocoena. (A) August and (B) September kernel density utilization grids for harbour porpoise PTT7235. Densities are presented in percentiles
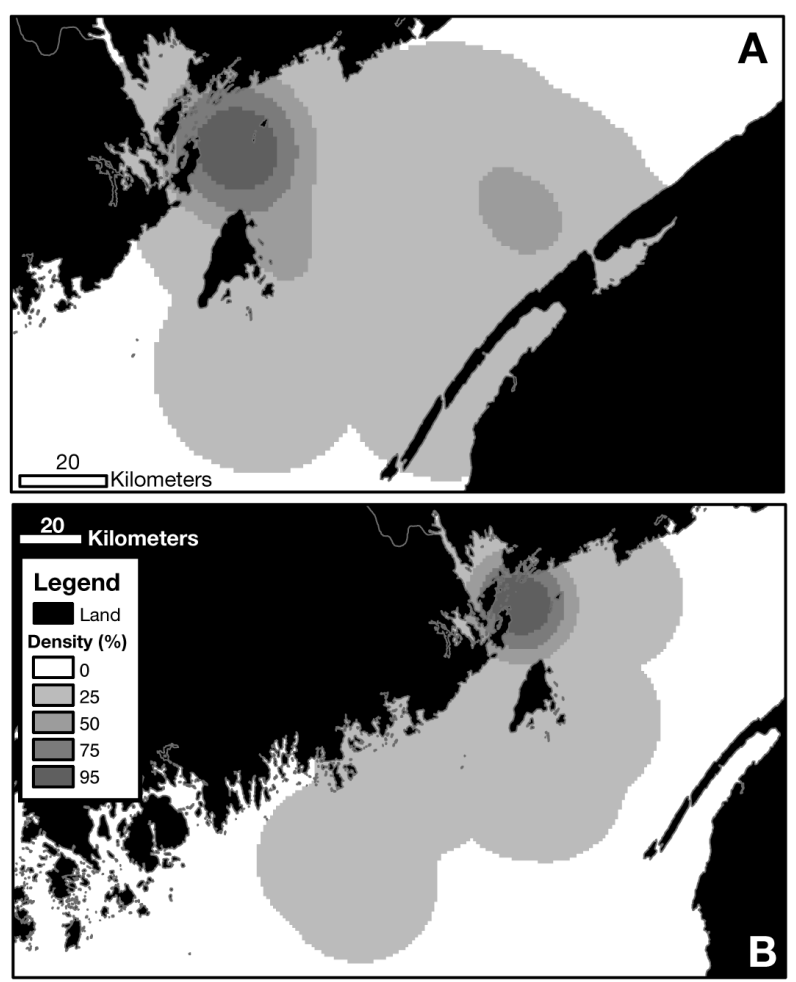

Fig. 3. Phocoena phocoena. (A) August and (B) September kernel density utilization grids for harbour porpoise PTT7244. Densities are presented in percentiles
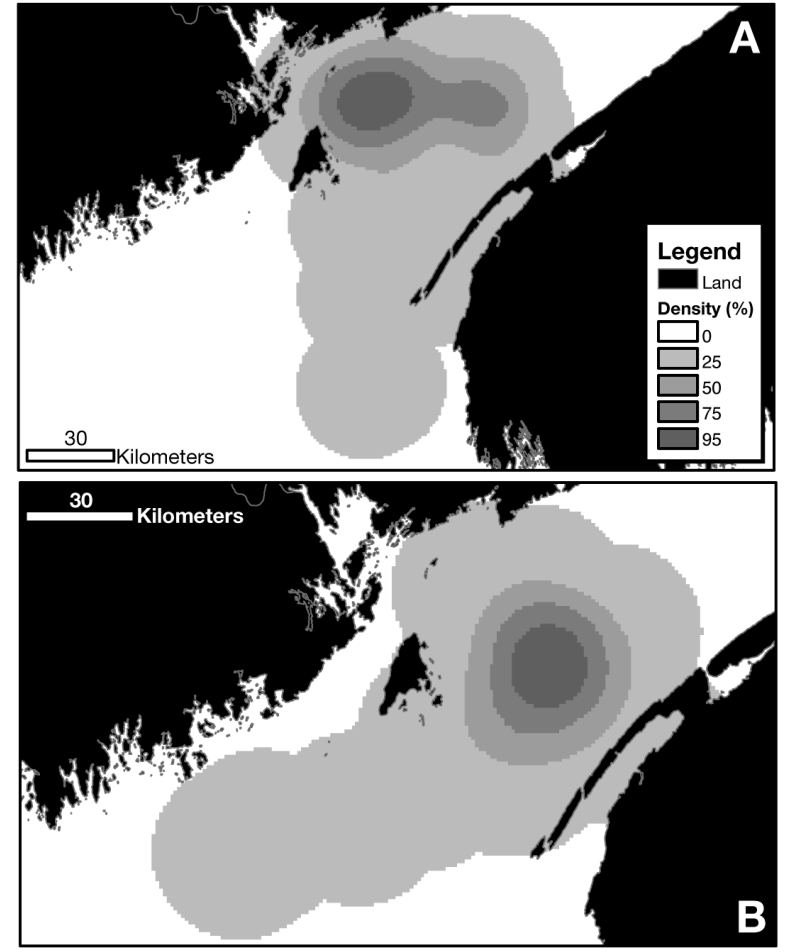

Fig. 4. Phocoena phocoena. (A) August and (B) September kernel density utilization grids for harbour porpoise PTT16291. Densities are presented in percentiles
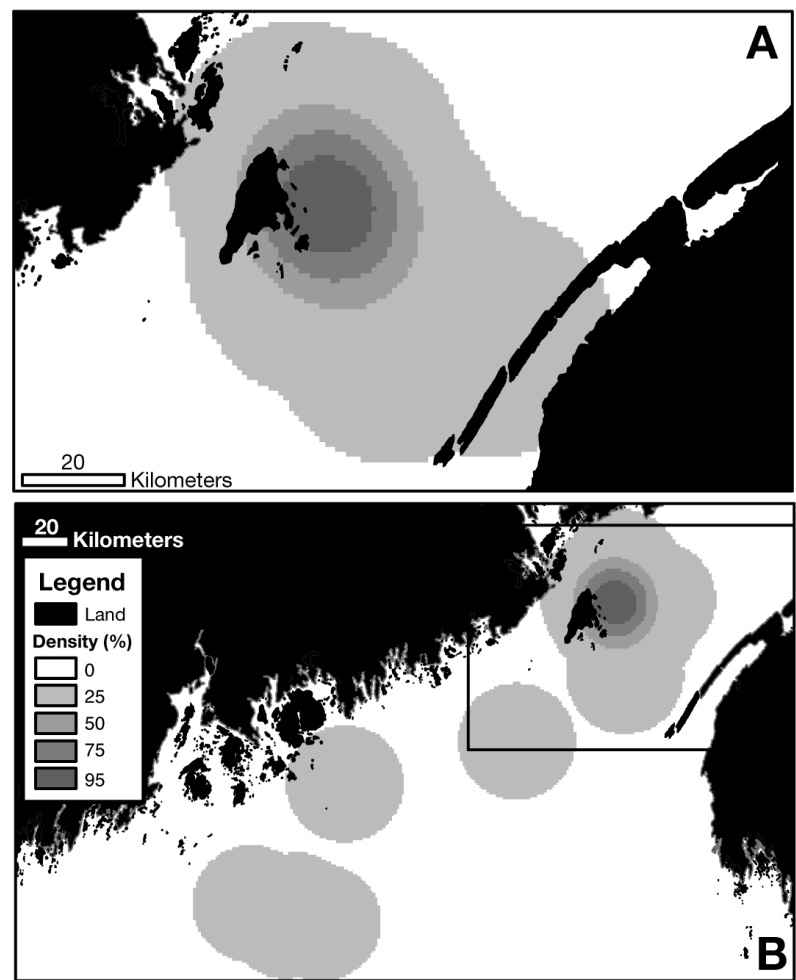

Fig. 5. Phocoena phocoena. (A) August and (B) September kernel density utilization grids for harbour porpoise PTT7250. Densities are presented in percentiles 

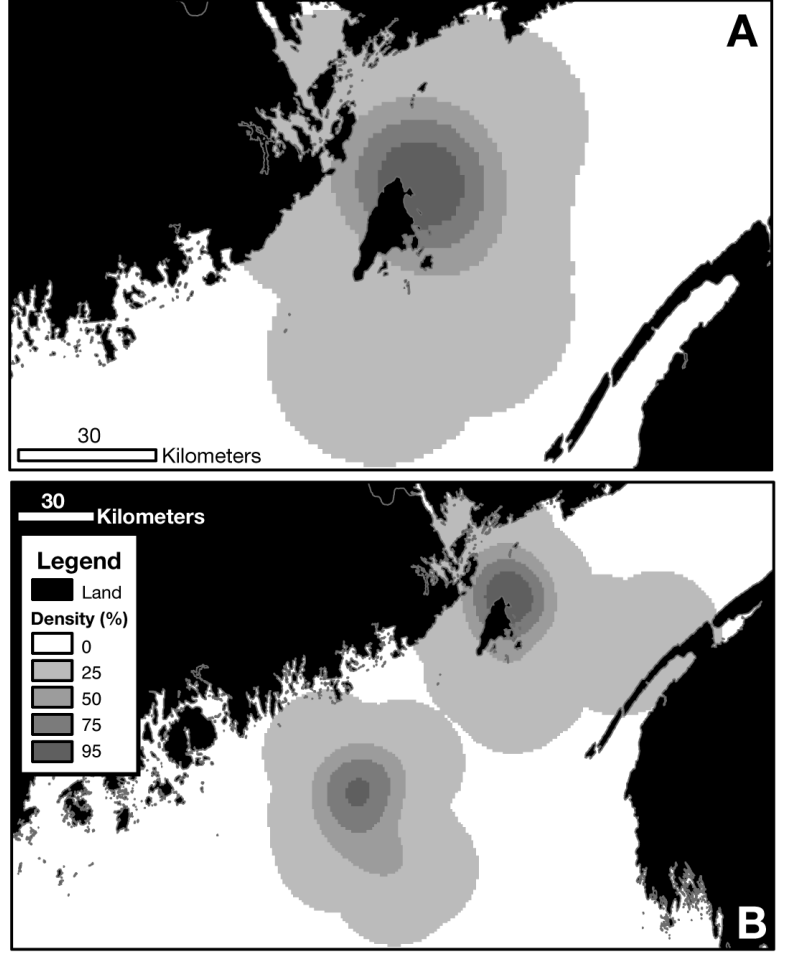

Fig. 6. Phocoena phocoena. (A) August and (B) September kernel density utilization grids for harbour porpoise PTT16300. Densities are presented in percentiles
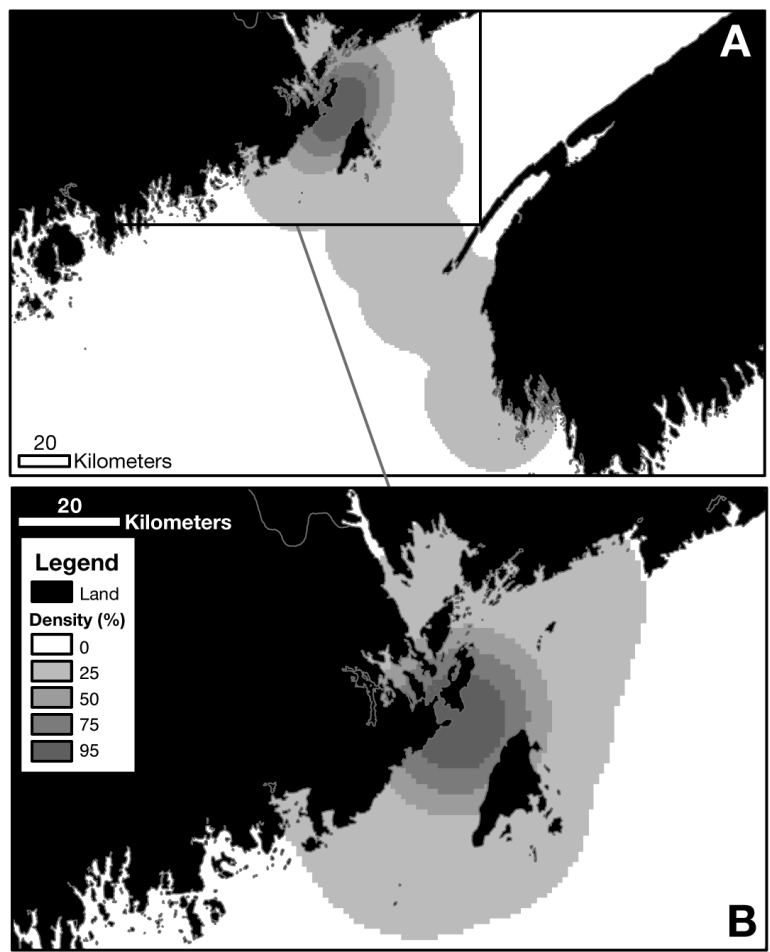

Fig. 7. Phocoena phocoena. (A) August and (B) September kernel density utilization grids for harbour porpoise PTT8531. Densities are presented in percentiles

\section{Line transects and distance sampling}

We conducted a total of 45 line transect surveys (25 surveys during flood tide phases and 20 during ebb tides) in 9 days during August 2000. This resulted in a total of $185.3 \mathrm{~km}$ of survey effort, $102.9 \mathrm{~km}$ during flood tide phases and $82.3 \mathrm{~km}$ during ebb phases. The detection probabilities and the detection function model illustrated a wide 'shoulder', where the detection probability remained high $(>0.80)$ out to $200 \mathrm{~m}$ from the trackline-a property that provides for more reliable density estimation (Thomas et al. 2002a). The numerical results of distance sampling analysis are presented in Table 3. There was a dramatic increase in the encounter rate, density of porpoises and porpoise groups, and relative abundance during the flood tide phase. The number of porpoises within the study area was 5.3 times higher during flood tides compared to ebb tides.

\section{Hydro-acoustic prey surveys}

The hydro-acoustic survey design provided limited information on the distribution of acoustic targets in the oceanographic feature due to the short interval of recordings actually taken within it. Typically the visible extent of the oceanographic feature only occurred during a very short segment (50 to $100 \mathrm{~m}$ ) of the transect. Values for the observed mean area backscatter for the 5 porpoise density transects and the alongfeature transect are presented in Table 4. Backscatter values for transects 1 to 5 were relatively consistent, but the transect we conducted along the feature revealed a much higher backscatter level (the minimum $18 \mathrm{~dB}$ difference is nearly 100 times the acrosstransect backscatter intensities). The high current velocities in the oceanographic feature greatly hampered our ability to conduct mid-water trawls. However, we were able to confirm that herring and euphausiids (primarily Meganyctiphanes norvegica) were present in the feature.

\section{SAR remote sensing}

The SAR image of the study area during flood tide revealed the presence of a large anti-cyclonic eddy and a frontal system that extended northeast of the tip of the island (Fig. 8B). Following mid-flood, this feature was approximately $3430 \mathrm{~m}$ long and extended from the island at an azimuth of approximately $26^{\circ}$. The eddy was approximately $2044 \mathrm{~m}$ wide. These data are consistent with the results of our preliminary theodolite survey for line transects described above. The SAR 
Table 3. Phocoena phocoena. Sighting probability, strip width, encounter rates, group density and size, density and relative abundance of harbour porpoises sighted during line transects $(\mathrm{n}=25$ for flood, $\mathrm{n}=20$ for ebb) off the northern tip of Grand Manan Island in the Bay of Fundy

\begin{tabular}{|lccccc|}
\hline & Mean & SE & CV $(\%)$ & \multicolumn{2}{c|}{$95 \%$ CI } \\
\hline Flood & & & & & \\
$f(0)$ & $3.43 \times 10^{-3}$ & $1.92 \times 10^{-4}$ & 5.59 & $3.07 \times 10^{-3}$ & $3.83 \times 10^{-3}$ \\
Sighting probability & 0.32913 & $1.84 \times 10^{-2}$ & 5.59 & 0.29487 & 0.36737 \\
Effective strip width (m) & 291.72 & 16.304 & 5.59 & 261.35 & 325.61 \\
Encounter rate & $2.35 \times 10^{-3}$ & $3.62 \times 10^{-4}$ & 15.4 & $1.71 \times 10^{-3}$ & $3.22 \times 10^{-3}$ \\
Group density (m ${ }^{-2}$ ) & $4.03 \times 10^{-6}$ & $6.60 \times 10^{-7}$ & 16.38 & $2.89 \times 10^{-6}$ & $5.61 \times 10^{-6}$ \\
Expected group size & 2.3811 & 0.12634 & 5.31 & 2.1449 & 2.6432 \\
Density (km ${ }^{-2}$ ) & 9.59 & 1.65 & 17.22 & 6.79 & 13.56 \\
Relative abundance & 230 & 39.602 & 17.22 & 162 & 324 \\
Ebb & & & & & \\
$f(0)$ & $3.43 \times 10^{-3}$ & $1.92 \times 10^{-4}$ & 5.59 & $3.07 \times 10^{-3}$ & $3.83 \times 10^{-3}$ \\
Sighting probability & 0.32913 & $1.84 \times 10^{-2}$ & 5.59 & 0.29487 & 0.36737 \\
Effective strip width $(\mathrm{m})$ & 291.72 & 16.304 & 5.59 & 261.35 & 325.61 \\
Encounter rate & $6.43 \times 10^{-4}$ & $1.52 \times 10^{-4}$ & 23.6 & $3.95 \times 10^{-4}$ & $1.05 \times 10^{-3}$ \\
Group density (m ${ }^{-2}$ ) & $1.10 \times 10^{-6}$ & $2.67 \times 10^{-7}$ & 24.25 & $6.71 \times 10^{-7}$ & $1.81 \times 10^{-6}$ \\
Expected group size & 1.6226 & 0.22087 & 13.61 & 1.2363 & 2.1296 \\
Density (km ${ }^{-2}$ ) & 1.79 & 0.50 & 27.81 & 1.03 & 3.11 \\
Relative abundance & 43 & 11.957 & 27.81 & 25 & 75 \\
\hline
\end{tabular}

image also revealed the presence of a fine-scale headland wake originating from the northern tip of Campobello Island (Fig. 9B). This feature is much smaller than the island wake, extending $721 \mathrm{~m}$ from the point at an azimuth of $348^{\circ}$.

\section{LANDSAT CanImage remote sensing}

The flood tide LANDSAT image also revealed the presence of both oceanographic features. The island wake originating off the northern tip of Grand Manan (Fig. 8C) extended northeast from the island at an azimuth of approximately $32^{\circ}$ and was $3600 \mathrm{~m}$ long. The headland wake originated on the northeast tip of Campobello Island (Fig. 9C) and was approximately $1000 \mathrm{~m}$ long and separated from the tip of the island at an azimuth of $323^{\circ}$ before curving southwards to parallel the axis of Head Harbour Passage.

Table 4. Mean transect length and depth-averaged mean surface-area backscatter for hydro-acoustic prey surveys conducted off the northern tip of Grand Manan Island in the Bay of Fundy

\begin{tabular}{|c|c|c|c|c|}
\hline \multirow{2}{*}{ Transect } & \multirow[t]{2}{*}{$\mathrm{n}$} & \multirow[t]{2}{*}{ Distance (km) } & \multicolumn{2}{|c|}{ Mean backscatter } \\
\hline & & & $\mathrm{m}^{-2}(\mathrm{~dB})$ & $\mathrm{SD}$ \\
\hline 1 & 4 & 3.34 & -48.24 & 15.86 \\
\hline 2 & 4 & 4.10 & -54.11 & 15.08 \\
\hline 3 & 4 & 4.38 & -55.68 & 10.50 \\
\hline 4 & 4 & 3.76 & -50.31 & 4.82 \\
\hline 5 & 4 & 3.24 & -59.52 & 24.40 \\
\hline Along & 1 & 7.02 & -30.65 & \\
\hline
\end{tabular}

\section{DISCUSSION}

The results of our analysis indicate that harbour porpoises have restricted focal regions within their summer monthly ranges and support our hypothesis that these focal areas coincide with fine-scale oceanographic features driven by tidal circulation. Furthermore, our results support Gaskin's original hypothesis that these features serve to aggregate prey and make it more available to upper trophic level predators, such as harbour porpoises. This enhanced prey availability likely results from the physical effects of finescale oceanographic features, such as island and headland wakes in tidal flow, which aggregate plankton and weak nekton. The details of each section of the study, and 2 integrative examples, are discussed below.

\section{Satellite telemetry}

Harbour porpoises use restricted focal areas in the Bay of Fundy during the late summer. The size of each monthly focal area was quite small-ranging from 122 to $415 \mathrm{~km}^{2}$. This finding is particularly striking given the mobility of these animals (Read \& Westgate 1997), which suggested that the monthly habitat available to a porpoise encompasses the entire Bay of Fundy and Gulf of Maine.

Kernel density functions (Worton 1989, Seaman \& Powell 1996) represent the best method for estimating utility distributions for animals (Powell 2000). Most studies employ kernel density estimates of habitat utilization to describe areas within which an animal is most likely to be found while engaging in its daily routine of foraging, resting and social behaviourreferred to as its home range (Burt 1943). In the present analysis, however, we use kernel density estimation to identify focal regions within the distribution of each animal. A similar approach was employed by Kenney \& Winn (1985) to identify 'high use' cetacean habitat in the northeastern United States using aerial survey and platform of opportunity data. The calculation of kernel density estimates does not require serial independence of observations (De Solla et al. 1999), but several studies have addressed spatial autocorrelation by restrictive sampling regimes or through post hoc sub-sampling or averaging of data (e.g. HeideJorgensen et al. 2002). Other researchers have noted that such corrections can result in biased utilization 


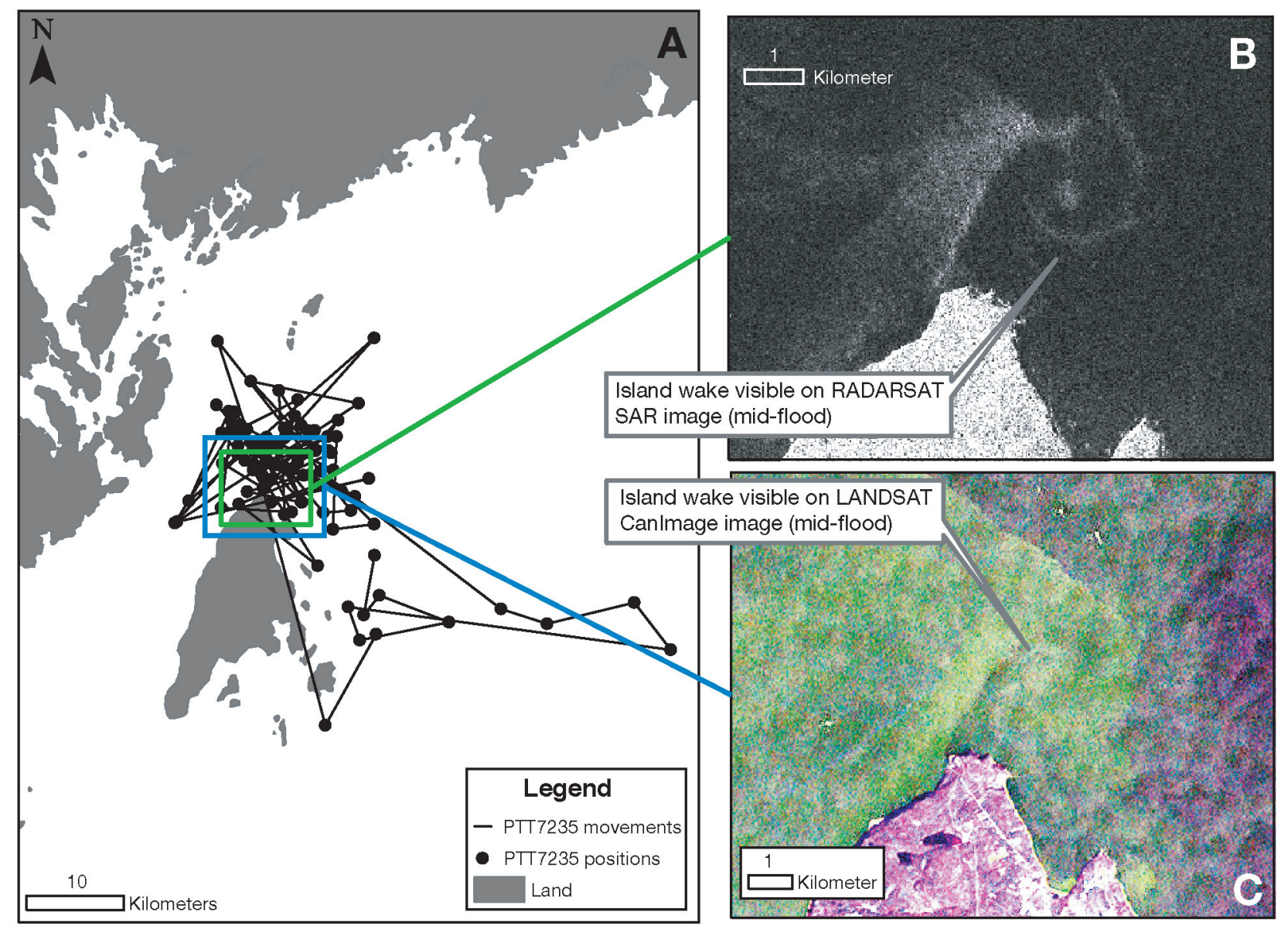

Fig. 8. Phocoena phocoena. (A) Spatial relationships between the August movements of harbour porpoise PTT7235 and the Long Eddy island wake forming off the northern tip of Grand Manan on flood tides as visualized by (B) RADARSAT synthetic aperture radar and (C) LANDSAT remote sensing imagery

grids (e.g. Reynolds \& Laundre 1990) and tend to reduce the biological relevance of the analysis (Lair 1987, De Solla et al. 1999). Our approach reduced the chance of producing biased estimates and ensured that time intervals between positions was short enough to capture the fine-scale movements of each animal (Cameron \& Spencer 1985).

Many studies have revealed that patterns in the distribution of cetaceans correlate well with physical features within the available habitat (e.g. Selzer \& Payne 1988, Hooker et al. 2002), and it is now becoming clear that such hotspots are likely related to foraging behavior (Hastie et al. 2004). This is likely to be true for harbour porpoises in the Bay of Fundy. Harbour porpoises must remain close to food resources and consume prey frequently to meet the energetic demands of maintenance, growth, and reproduction (Koopman 1998). This is especially true for mature female porpoisesconsidered to be income breeders (Read 2001) - that must meet the costs of pregnancy and lactation through increased energy intake rather than relying on energy stores (Sibly \& Calow 1986). Unfortunately, we had only 1 female in our sample and cannot, therefore, draw comparisons between males and females. The focal areas of most porpoises (5 out of 6 ), were coastal in nature, and the focal regions of 4 animals (PTT7235, PTT7244, PTT8531 and PTT16300) were proximate to headlands, restricted channels or the tips of islands. Only 1 animal, PTT16291, focused its movements away from land, at the northern edge of the Grand Manan basin.

Each of these focal regions represents a unique location in terms of depth, bottom slope, and distance from shore, illustrating why previous attempts to build predictive models of porpoise habitat using these types of physical features (e.g. Watts \& Gaskin 1985, Cox 2003) have been largely unsuccessful. Indeed, physical features such as depth, slope and distance from shore may be poor proxies for describing cetacean habitat, as they are at least one step removed from the actual elements the model seeks to describe. At fine-scales, cetacean habitat could be better described by modeling the 


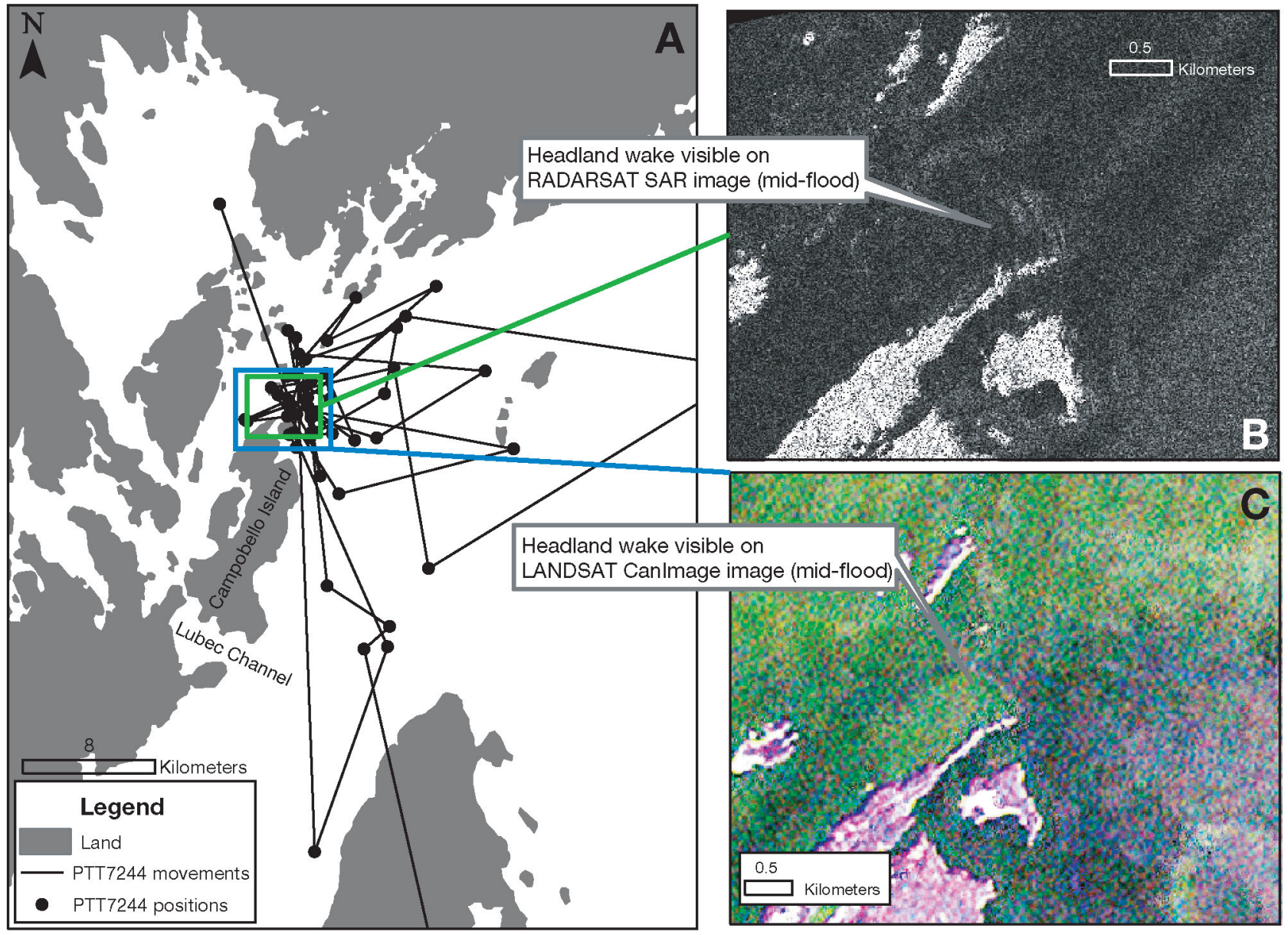

Fig. 9. Phocoena phocoena. (A) Spatial relationships between the September movements of harbour porpoise PTT7244 and the Head Harbour headland wake forming off the northern tip of Campobello Island on flood tides as visualized by

(B) RADARSAT synthetic aperture radar and (C) LANDSAT remote sensing imagery

interactions between these physical features and timevariant phenomena such as winds, currents, tides, day length and time of day. For example, the region off the northern tip of Grand Manan exhibits a relatively gentle slope, yet the areas at both ends of Campobello Island exhibit rapid changes in depth with proximity to shore. These locations are likely to exhibit different current regimes, but all 3 areas exhibit enhanced relative vorticity (see Mann \& Lazier 1996) due to the interactions between fast tidal currents and shoreline configuration (Signell 1989, Signell \& Geyer 1991). Both PTT8531 and PTT7244 exhibited focal regions coinciding with the restricted passages into the inshore waters of the Quoddy Region proximate to Campobello Island. Animal PTT8531 focused on the entrance to the Lubec Channel, an area of high tidal velocity on both ebb and flood tides, and PTT7244's focal region was adjacent to the northeastern tip of Campobello Island. This latter area was intensively studied by David Gaskin's research group in the early 1980s and is known to attract large numbers of marine predators to forage within eddies and upwellings produced on flood tides (Gaskin 1983, Smith et al. 1984).

Two porpoises (PTT7235 and PTT16300) exhibited overlapping focal areas at the northern tip of Grand Manan Island. Previous studies have revealed that porpoise abundance can be high in this region, especially during flood tides (Read 1983). As well, an early treatise on the hunting of harbour porpoises in the Bay of Fundy noted that members of the Passmaquoddy tradition knew that this region was frequented by porpoises that fed on abundant schools of herring and mackerel (Ward 1880). This feature is commonly referred to by local people as the Long Eddy.

\section{Line transects and prey surveys}

Our line transects revealed that relative porpoise density was highest in our fine-scale study area during 
flood tides. It is difficult to compare the results of our uncorrected surveys with density estimates generated by other line transect surveys for harbour porpoises, due to differences in observation platforms, corrections for animals missed on the trackline and changes in the behaviour of animals in response to survey vessels (Palka \& Hammond 2001). Porpoise densities in the Long Eddy during flood tides were more than an order of magnitude higher than estimates of corrected porpoise densities (adjusted for animals missed on the trackline) found by Hammond et al. (2002) in the North Sea and adjacent waters. The density estimate during ebb tide phases in the present study (1.79 porpoises $\mathrm{km}^{-2}$ ) was similar to uncorrected estimates found by Palka (1995) for high-density regions of the Gulf of Maine (1.46 to 3.97 porpoises $\mathrm{km}^{-2}$ ). This is not surprising, perhaps, considering that some of Palka's (1995) high-density stratum surveys overlapped with our study area. However, our flood estimates of density are up to 3 times higher than Palka's (1995), suggesting that consideration of tide phase may be important when conducting surveys for porpoises in tidally active regions.

We found it very difficult to assess the availability of prey within the Long Eddy due to the high current velocities and the dynamic nature of the system. However, our hydro-acoustic survey results suggest that prey is concentrated along the length of the feature and that these prey concentrations contain Atlantic herring and euphausiids, the prey of juvenile and adult porpoises. Hydro-acoustic methods have been employed successfully in other marine mammal foraging studies, for example, to assess changes in the quality, depth and location of the meso-pelagic scattering layer near the Hawaii islands in relation to foraging spinner dolphins (Benoit-Bird \& Au 2003). Further research is required to develop robust acoustic and traditional sampling procedures for highly dynamic oceanographic features like the Long Eddy.

Our line transect results complement the analyses of satellite telemetry data and illustrate that harbour porpoises congregate in this region during flood tides. A wide variety of marine predators exploit fine-scale fronts, upwellings and eddies while foraging. For example, foraging basking sharks use small-scale oceanic fronts (Sims \& Quayle 1998); indeed, it is becoming apparent that some important aspects of the social behaviour of these animals may depend on the predictable occurrence of these fronts (Sims et al. 2000). Seabirds exploit coastal fronts in the North Pacific (Decker \& Hunt 1996, Hunt et al. 1996), feeding primarily on small fishes which aggregate there to consume zooplankton. Similar patterns have been found for prions Pachyptila sp. that use fine-scale oceanographic features within the Antarctic Polar Front (van
Franeker et al. 2002); there are numerous other examples of seabirds foraging in regions of enhanced relative vorticity (reviewed in Hunt \& Schneider 1987). Sea turtles also associate with oceanic fronts (Polovina et al. 2000), and the observations of several species of large pelagic fishes correlate with larger-scale oceanographic phenomena (Barkley 1972, Polovina et al. 2001).

A growing number of examples link marine mammal foraging behavior to oceanographic phenomena, although most observations have been made at larger spatial scales than those examined in the present study. For example, Griffin (1999) found that sperm whales were associated with the edges of warm core Gulf Stream rings as they encountered the continental shelf of the eastern US, presumably feeding on squid which occur in the faster-moving water at the edges of the ring. Similar relationships have been found for sperm whales in the Gulf of Mexico (e.g. Biggs et al. 2000). Pinnipeds are also known to exploit fine-scale oceanographic features for foraging. For example, Zamon (2001) found that harbour seals Phoca vitulina richardsii foraged in tidal currents within restricted channels in the San Juan Islands, WA, preying upon aggregations of schooling fish. Similarly, Mendes et al. (2002) found that bottlenose dolphins Tursiops truncatus associated with the surface features of a tidal intrusion in the inner Moray Firth, presumably to exploit accumulations of prey in a front which formed between brackish river outflow and saline oceanic tide waters.

\section{Remote sensing and integrative examples}

Both the LANDSAT and RADARSAT images confirm the presence of a front and eddy system-an island wake-forming off the northern tip of Grand Manan Island on flood tides. This is the first demonstration of the formation of an island wake forming behind Grand Manan Island in tidal flow, and there are no detailed examinations of the local physical or biological oceanography to draw on for comparison. However, as noted above, Ward (1880) reported that aboriginal people in the area knew about and understood the complex pattern of fronts and eddies caused by the obstruction of Grand Manan to tidal currents. These images provide context for the high density of porpoises in our fine-scale study area on flood tides and help explain the locations of the focal regions of PTT7235 and PTT16300. They also provide details on the physical mechanisms that regulate the system (see below).

Both images also indicate that a similar feature occurs within the core range of PTT7244, near the northern tip of Campobello Island. Here a headland 
wake forms on flood tides, as rapid tidal flow inshore is obstructed by the northern tip of the island. Previous studies of the oceanographic regime in this localized area described little coherence in the complex pattern of upwellings and fronts found there and suggested that they originated from a combination of rapid tidal flow over sharp reductions in depth (Smith et al. 1984) and, possibly, island mass effects. Our observations confirm the latter portion of this hypothesis, revealing a headland wake in the vicinity of the greatest temperature anomalies and plankton and fish accumulations in that region (Smith et al. 1984). We did not conduct line transects in this area to confirm whether porpoises congregate in this feature, but previous surveys in or near this feature reported more than twice the number of porpoise sightings in this region compared with other inshore areas (Watts \& Gaskin 1985). In addition, Berggren (1995) surveyed this area in 1990 and 1991 and found similar results: porpoise densities were consistently high in this area.

The production of eddies and fronts downstream from obstructions to flow is a common phenomena, existing at spatial scales ranging from rocks in freshwater streams (Crowder \& Diplas 2000) to entire islands in geostrophic flow in oceanic systems (Caldeira et al. 2002). These phenomena-referred to as island stirring effects (Arístegui et al. 1997), island mass effects (Doty \& Oguri 1956) or island wakes (e.g. Coutis \& Middleton 2002) - have significant effects on biological systems (Coutis \& Middleton 2002). Island and headland wakes are known to increase nutrient levels (St. John \& Pond 1992), stimulate primary production (St. John et al. 1992, St. John \& Pond 1992), aggregate plankton (Alldredge \& Hamner 1980) and the larvae of fish, crustaceans and molluscs and their predators (Wolanski \& Hamner 1988, Rankin et al. 1994). Prey aggregations within headland and island wakes are believed to result from complex secondary flows which concentrate plankton and weak nekton near the surface at convergences and at the edges of eddies (Wolanski \& Hamner 1988, Mann \& Lazier 1996).

Figs. 8 \& 9 are integrative examples of porpoise movements in relation to fine-scale oceanographic features detected by remote sensing. In both cases, the focal region in the porpoises range corresponded with the location of a topographically controlled oceanographic feature that can aggregate plankton and weak nekton (Wolanski \& Hamner 1988). Both PTT7235 and PTT7244 appear to have focused on relatively small areas proximate to an island wake and a headland wake respectively. These systems would provide predictable concentrations of prey throughout the summer months.

We sub-sampled our telemetry data to provide a standard sampling rate and comparable kernel density estimates between porpoises, but examining the over- all telemetry records from individual animals can elucidate, in greater detail, the importance of these features. For example, PTT7235 spent $45 \mathrm{~d}$ in the Bay of Fundy (2 Aug to $20 \mathrm{Sept}$ ); we received a minimum of 1 position within $5 \mathrm{~km}$ of the center of the Long Eddy on $32(71 \%)$ of these days and at least 1 position within $10 \mathrm{~km}$ of Long Eddy on 42 (93\%) of these days.

Foraging theory predicts that predators should spend more time in areas of abundant accessible prey, thereby maximizing the energetic profitability of their efforts (MacArthur \& Pianka 1966, Stephens \& Krebs 1986). This type of behavior can be detected by looking for changes in speeds and turning rates in the movements of animals, where they are expected to slow down and turn more frequently in regions of greater prey abundance-often referred to as an arearestricted search pattern (Tinbergen et al. 1967, Krebs et al. 1978, Stephens \& Krebs 1986, Kareiva \& Odell 1987, Fauchald \& Tveraa 2003). We cannot accurately measure the rate of travel for our porpoises, and our standardized sampling rate limits our ability to quantify turn rates and radii in their fine-scale movements. However, chronological reconstructions of the paths of both PTT7235 and PTT7244 clearly illustrate that both animals made occasional forays away from their core areas, followed by movements back into the core region. This suggests that these porpoises likely encountered greater prey densities in their focal regions and that they restricted their movement patterns to maximize energetic profitability.

\section{CONCLUSIONS}

Our observations suggest the porpoises target specific regions of enhanced relative vorticity, such as island and headland wakes, as foraging sites during the summer months in the Bay of Fundy. Not all porpoises choose the same focal regions, indicating that some level of specialization in foraging habitat use may exist. However, 3 out of the 6 tagged porpoises chose regions that exhibit predictable, tidally induced fine-scale oceanographic features clearly detectable with remote sensing techniques. Further research is required to assess whether individual harbour porpoises specialize within specific habitats, as occurs in other marine mammals (Estes et al. 2003). These oceanographic features likely enhance foraging efficiency for porpoises by aggregating prey in a predictable manner in localized areas. Integration of data from satellite telemetry, line transect surveys and remote sensing of oceanographic features would be a useful way of developing objective criteria for designating critical habitat for harbour porpoises in the Bay of Fundy and elsewhere. 
Acknowledgements. This work was supported by research grants and in-kind support from the Disney Conservation Foundation, the Duke University Marine Laboratory, the International Fund for Animal Welfare and Radarsat International's Data for Research Use Program. We would like to thank Heather Koopman, Lesley Thorne and the staff of the Grand Manan Whale and Seabird Research station for field and logistical support. We would like to thank Gary Melvin and the Department of Fisheries and Oceans for help with the hydro-acoustic surveys and net sampling. Portions of this manuscript were improved by comments from Richard Barber, Larry Crowder, Damon Gannon, Kerry Irish, Doug Nowacek and 4 anonymous reviewers. This research was conducted under permits from the Canadian Department of Fisheries and Oceans and with approval from the Duke University Institutional Animal Care \& Use Committee (IACUC).

\section{LITERATURE CITED}

Alldredge AL, Hamner WM (1980) Recurring aggregation of zooplankton by a tidal current. Estuar Coast Mar Sci 10: $31-37$

Anonymous (2002) CanImage (Landsat 7 orthoimages at the 1:50000 scale). Standards and specifications. Centre for Topographic Information Customer Support Group, Sherbrooke, QC

Arístegui J, Tett P, Hernandez-Guerra A, Basteretxea G and 8 others (1997) The influence of island-generated eddies on chlorophyll distribution: a study of mesoscale variation around Gran Canaria. Deep-Sea Res I 44:71-96

Austin D, McMillan JI, Bowen WD (2003) A three-stage filtering algorithm for filtering erroneous Argos satellite locations. Mar Mamm Sci 19:371-383

Barkley RA (1972) Johnston Atoll's wake. J Mar Res 30: 201-216

Baumgartner MF, Cole TVN, Clapham PJ, Mate BR (2003) North Atlantic right whale habitat in the lower Bay of Fundy and on the SW Scotian Shelf during 1999-2001. Mar Ecol Prog Ser 264:137-154

Benoit-Bird KJ, Au WW (2003) Prey dynamics affect foraging by a pelagic predator (Stenella longirostris) over a range of spatial and temporal scales. Behav Ecol Sociobiol 53: 364-373

Berggren P (1995) Stocks, status and survival of harbour porpoises in Swedish waters. PhD thesis, Stockholm University

Biggs DC, Leben RR, Ortega OJG (2000) Ship and satellite studies of mesoscale circulation and sperm whale habitats in the Northeast Gulf of Mexico during GulfCet II. Gulf Mexico Sci 18:15-22

Brodie PF, Sameoto DD, Sheldon RW (1978) Population densities of euphausiids off Nova Scotia as indicated by net samples, whale stomach contents and sonar. Limnol Oceanogr 23:1264-1267

Buckland ST, Anderson DR, Burnham KP, Laake JL (1993) Distance sampling: estimating abundance of biological populations. Chapman \& Hall, London

Burt WH (1943) Territoriality and home range concepts as applied to mammals. J Mammal 24:346-352

Caldeira RMA, Groom S, Miller P, Pilgrim D, Nezlin NP (2002) Sea-surface signatures of the island mass effect phenomena around Madeira Island, Northeast Atlantic. Remote Sensing Environ 80:336-360

Cameron GN, Spencer SR (1985) Assessment of space-use patterns in the hispid cotton rat (Sigmodon hispidus). Oecologia 68:133-139
Charnov EL (1976) Optimal foraging: The marginal value theorem. Theor Popul Biol 9:129-136

Coutis PF, Middleton JH (2002) The physical and biological impact of a small island wake in the deep ocean. DeepSea Res I 49:1341-1361

Cox TM (2003) Evaluation of strategies to reduce bycatch of harbor porpoises (Phocoena phocoena). PhD thesis, Duke University, Durham, NC

Crowder DW, Diplas P (2000) Using two-dimensional hydrodynamic models at scales of ecological importance. J Hydrol 230:172-191

Dawson S, Slooten E, DuFresne S, Wade PR, Clement D (2004) Small-boat surveys for coastal dolphins: linetransect surveys for Hector's dolphins. Fish Bull 102: $441-451$

Decker MB, Hunt GL Jr (1996) Foraging by murres (Uria spp.) at tidal fronts surrounding the Pribilof Islands, Alaska, USA. Mar Ecol Prog Ser 139:1-10

De Solla SR, Bonduriansky R, Brooks RJ (1999) Eliminating autocorrelation reduces biological relevance of home range estimates. J Anim Ecol 68:221-234

Doty MS, Oguri M (1956) The island mass effect. J Cons Int Explor Mer 22:33-37

Ekstrand S (1992) Landsat Tm-based quantification of chlorophyll a during algae blooms in coastal waters. Int J Remote Sensing 13:1913-1926

Estes JA, Riedman ML, Staedler MM, Tinker MT, Lyon BE (2003) Individual variation in prey selection by sea otters: patterns, causes and implications. J Anim Ecol 72: $144-155$

Farmer DM, D'Asaro EA, Trevorrow MV, Dairiki GT (1995) Three-dimensional structure in a tidal convergence front. Cont Shelf Res 15:1649-1673

Fauchald P, Tveraa T (2003) Using first-passage time in the analysis of area-restricted search and habitat selection. Ecology 84:282-288

Gannon DP, Craddock JE, Read AJ (1998) Autumn food habits of harbor porpoises, Phocoena phocoena, in the Gulf of Maine. Fish Bull (Wash DC) 96:428-437

Gaskin DE (1983) The marine mammal community. In: Thomas MLH (ed) Marine and coastal systems of the Quoddy Region, New Brunswick. Can Spec Publ Fish Aquat Sci 64:245-268

Gaskin DE (1984) The harbour porpoise Phocoena phocoena (L.): regional populations, status, and information on direct and indirect catches. Rep Int Whaling Comm 34: 569-586

Griffin RB (1999) Sperm whale distributions and community ecology associated with a warm-core ring off Georges Bank. Mar Mamm Sci 15:33-52

Hammond PS, Berggren P, Benke H, Borchers DL and 6 others (2002) Abundance of harbour porpoise and other cetaceans in the North Sea and adjacent waters. J Appl Ecol 39:361-376

Hastie G, Wilson B, Wilson LJ, Parsons KM, Thompson PM (2004) Functional mechanisms underlying cetacean distribution patterns: hotspots for bottlenose dolphins are linked to foraging. Mar Biol 144:397-403

Heide-Jorgensen MP, Dietz R, Laidre KL, Richard P (2002) Autumn movements, home ranges, and winter density of narwhals (Monodon monoceros) tagged in Tremblay Sound, Baffin Island. Polar Biol 25:331-341

Hooge PN, Eichenlaub B (1997) Animal movement extension to Arcview. Alaska Science Center - Biological Science Office, US Geological Survey, Anchorage, AK

Hooker SK, Whitehead H, Gowans S, Baird RW (2002) Fluctuations in distribution and patterns of individual range use 
of northern bottlenose whales. Mar Ecol Prog Ser 225: 287-297

Hunt GL, Schneider DC (1987) Scale-dependent processes in the marine environment. In: Croxall JP (ed) Seabirds feeding ecology and role in marine ecosystems. Cambridge University Press, Cambridge, p 7-43

Hunt GL Jr, Coyle KO, Hoffman S, Decker MB, Flint EN (1996) Foraging ecology of short-tailed shearwaters near the Pribilof Islands, Bering Sea. Mar Ecol Prog Ser 141: $1-11$

Hyrenbach KD, Dotson RC (2001) Post-breeding movements of a male Black-footed Albatross Phoebastria nigripes. Mar Ornithol 29:7-10

Hyrenbach KD, Fernandez P, Anderson DJ (2002) Oceanographic habitats of two sympatric North Pacific albatrosses during the breeding season. Mar Ecol Prog Ser 233: 283-301

Johnston DW (2002) The effect of acoustic harassment devices on harbour porpoises (Phocoena phocoena) in the Bay of Fundy, Canada. Biol Conserv 108:113-118

Jovallanos CL, Gaskin DE (1983) Predicting the movements of juvenile Atlantic herring (Clupea harengus herengus) in the SW Bay of Fundy using computer simulation techniques. Can J Fish Aquat Sci 40:139-146

Kareiva PM, Odell G (1987) Swarms of predators exhibit 'preytaxis' if individual predators use area-restricted search. Am Nat 130:223-270

Kenney RD, Winn HE (1985) Cetacean high use habitats of the northeast United States continental shelf. Fish Bull 84: 345-356

Koopman HN (1998) Topographical distribution of the blubber of harbor porpoises (Phocoena phocoena). J Mammal 79:260-270

Krebs JR, Kacelnik A, Taylor PJ (1978) Test of optimal sampling by foraging great tits. Nature 275:27-31

Lair H (1987) Estimating the location of the focal center in red squirrel home ranges. Ecology 68:1092-1101

Lu J (2003) Marine oil spill detection, statistics and mapping with ERS SAR imagery in south-east Asia. Int J Remote Sensing 24:3013-3032

Lubin D, Li W, Dustan P, Mazel CH, Stamnes K (2001) Spectral signatures of coral reefs: features from space. Remote Sensing Environ 75:127-137

MacArthur RH, Pianka ER (1966) On optimal use of a patchy environment. Am Nat 100:603-609

Mann KH, Lazier JRN (1996) Dynamics of marine ecosytems. Biological-physical interactions in the oceans. Blackwell Science, Malden, MA

Martinez A, Font J, Moreno V, Garcia E (1992) Sea surface mesoscale structures imaged by the synthetic aperture radar. Sci Mar 56:357-366

Mate BR, Lagerquist BA, Calambokidis J (1999) Movements of North Pacific blue whales during the feeding season off southern California and their southern fall migration. Mar Mamm Sci 4:1246-1257

McConnell BJ, Chambers C, Fedak MA (1992) Foraging ecology of southern elephant seals in relation to the bathymetry and productivity of the Southern Ocean. Antarct Sci 4:393-398

Melvin GD, Cochrane NA, Li Y (2003) Extraction and comparison of acoustic backscatter from a calibrated multi- and single-beam sonar. ICES J Mar Sci 60:669-677

Mendes S, Turrell W, Luetkebohle T, Thompson P (2002) Influence of the tidal cycle and a tidal intrusion front on the spatio-temporal distribution of coastal bottlenose dolphins. Mar Ecol Prog Ser 239:221-229

Neimanis AS, Koopman HN, Westgate AJ, Murison LD, Read
AJ (2004) Entrapment of harbour porpoises (Phocoena phocoena) in herring weirs in the Bay of Fundy, Canada. J Cetac Res Manag 6(1):7-17

Palka D (1995) Abundance estimates of the Gulf of Maine harbor porpoise. Rep Int Whaling Comm, Spec Iss 16:27-50

Palka DL, Hammond PS (2001) Accounting for responsive movement in line transect estimates of abundance. Can J Fish Aquat Sci 58:777-787

Polovina JJ, Kobayashi DR, Parker DM, Seki-Michael P, Balazs GH (2000) Turtles on the edge: movement of loggerhead turtles (Caretta caretta) along oceanic fronts, spanning longline fishing grounds in the central North Pacific, 1997-1998. Fish Oceanogr 9:71-82

Polovina JJ, Howell E, Kobayashi DR, Seki MP (2001) The transition zone chlorophyll front, a dynamic global feature defining migration and forage habitat for marine resources. Prog Oceanogr 49:1-4

Powell RA (2000) Animal home ranges, territories and home range estimators. In: Boitani L, Fuller TK (eds) Research techniques in animal ecology: controversies and consequences. Columbia University Press, New York, p 65-103

Rankin KL, Mullineaux LS, Geyer WR (1994) Transport of juvenile gem clams (Gemma gemma) in a headland wake. Estuaries 17:655-667

Read AJ (1983) Movements and distribution of harbour porpoises Phocoena phocoena (L.), in the western Bay of Fundy. MSc thesis, University of Guelph

Read AJ (1999) Harbour porpoise (Phocoena phocoena). In: Ridgeway SH, Harrison R (eds) Handbook of marine mammals. The second book of dolphins and porpoises, Vol 6 . Academic Press, San Diego, CA

Read AJ (2001) Trends in the maternal investment of harbour porpoises are uncoupled from the dynamics of their primary prey. Proc R Soc Biol Sci Ser B 268:573-577

Read AJ, Westgate AJ (1997) Monitoring the movements of harbour porpoises (Phocoena phocoena) with satellite telemetry. Mar Biol 130:315-322

Recchia CA, Read AJ (1989) Stomach contents of harbour porpoises, Phocoena-Phocoena (L.), from the Bay of Fundy, Canada. Can J Zool 67:2140-2146

Reynolds TD, Laundre JW (1990) Time intervals for estimating pronghorn and coyote home ranges and daily movements. J Wildl Manag 54:316-322

Ronconi RA, St. Clair CC (2002) Management options to reduce boat disturbance on foraging black guillemots (Cepphus grylle) in the Bay of Fundy. Biol Conserv 108: 265-271

Seaman DE, Powell RA (1996) An evaluation of the accuracy of kernel density estimators for home range analysis. Ecology (Wash DC) 77:2075-2085

Selzer LA, Payne PM (1988) The distribution of white-sided (Lagenorhynchus acutus) and common dolphins (Delphinus delphis) vs. environmental features of the continental shelf of the northeastern United States. Mar Mamm Sci 4: 141-153

Sibly RM, Calow P (1986) Physiological ecology of animals. Blackwell Scientific Publications, Oxford

Signell RP (1989) Tidal dynamics and dispersion around coastal headlands. PhD thesis, Woods Hole Oceanographic Institute, Woods Hole, and Massachusetts Institute of Technology, Cambridge

Signell RP, Geyer WR (1991) Transient eddy formation around headlands. J Geophys Res 96:2561-2575

Sims DW, Quayle VA (1998) Selective foraging behavior of basking sharks on zooplankton in a small-scale front. Nature 393:460-464 
Sims DW, Southall EJ, Quayle VA, Fox AM (2000) Annual social behaviour of basking sharks associated with coastal front areas. Proc R Soc Biol Sci Ser B 267:1897-1904

Smith GJD, Gaskin DE (1974) The diet of harbor porpoises, Phocoena phocoena, in coastal waters of eastern Canada with special reference to the Bay of Fundy. Can J Zool 52:777-782

Smith GJD, Jovallanos CL, Gaskin DE (1984) Near-surface bio-oceanographic phenomena in the Quoddy Region, Bay of Fundy. Can Tech Rep Fish Aquat Sci 1280:124

Smith RJ, Read AJ (1992) Consumption of euphausiids by harbour porpoise (Phocoena phocoena) calves in the Bay of Fundy. Can J Zool 70:1629-1632

Stephens DW, Krebs JR (1986) Foraging theory. Princeton University Press, Princeton, NJ

Stewart BS, Delong RL (1995) Double migrations of the northern elephant seal, Mirounga angustirostris. J Mammal 76: 196-205

St. John MA, Pond S (1992) Tidal plume generation around a promontory: effects on nutrient concentrations and primary productivity. Cont Shelf Res 12:339-354

St. John MA, Harrison PJ, Parsons TR (1992) Tidal wake mixing: localized effects on primary production and zooplankton distributions in the Strait of Georgia, British Columbia. J Exp Mar Biol Ecol 164:261-274

Teilmann J (2000) The behaviour and sensory abilities of harbour porpoises (Phocoena phocoena) in relation to bycatch in gillnet fishery. $\mathrm{PhD}$ thesis, University of Southern Denmark, Odense

Thomas L, Buckland ST, Burnham KP, Anderson DR, Laake JL, Borchers DL, Strindberg S (2002a) Distance sampling. In: ElShaarawi AH, Piegorsch WW (eds) Encyclopedia of environmetrics, Vol 1. John Wiley \& Sons, Chichester, p 544-552

Editorial responsibility: Otto Kinne (Editor-in-Chief), Oldendorf/Luhe, Germany
Thomas L, Laake JL, Strindberg S, Marques FFC and 6 others (2002b) Distance 4.0. Release 2. Research Unit for Wildlife Population Assessment (http://www.ruwpa.st-and.ac.uk/ distance/), University of St. Andrews

Tinbergen N, Impekoven M, Franck D (1967) An experiment on spacing-out as a defense against predation. Behaviour 28:307-320

van Franeker JA, van den Brink NW, Bathmann UV, Pollard RT, de Baar HJW, Wolff WJ (2002) Responses of seabirds, in particular prions (Pachyptila sp.), to small scale processes in the Antarctic Polar Front. Deep-Sea Res II 49: 3931-3950

Ward CC (1880) Porpoise-shooting. Scribners Mon 20:801-812

Watts P, Gaskin DE (1985) Habitat index analysis of the harbor porpoise Phocoena phocoena in the southern coastal Bay of Fundy, Canada. J Mammal 66:733-744

Westgate AJ, Read AJ (1998) Applications of new technology to the conservation of porpoises. Mar Technol Soc J 32: $70-81$

Wolanski E, Hamner WM (1988) Topographically controlled fronts in the ocean and their biological influence. Science 241:177-181

Wolanski E, Pickard GL, Jupp DLB (1984) River plumes, coral reefs and mixing in the Gulf of Papua and the Northern Great Barrier Reef, Papua New-Guinea, Australia. Estuar Coast Shelf Sci 18:291-314

Worton BJ (1989) Kernel methods for estimating the utilization distribution in home-range studies. Ecology 70: $164-168$

Zamon JE (2001) Seal predation on salmon and forage fish schools as a function of tidal currents in the San Juan Islands, Washington, USA. Fish Oceanogr 10:353-366

Submitted: August 10, 2004; Accepted: December 7, 2004 Proofs received from author(s): June 3, 2005 